\title{
Antimicrobial and Antitumor Properties of Medicinal and Spice Plants from Croatia
}

\author{
S Pepeljnjak* \\ Department of microbiology, Faculty of Pharmacy and Biochemistry, University of Zagreb, Croatia
}

Corresponding author: S Pepeljnjak, Department of microbiology, Faculty of Pharmacy and Biochemistry, University of Zagreb, Croatia

\section{ARTICLE INFO}

Received: 隠 October 07, 2020

Published: 㹃 October 16, 2020

Citation: S Pepeljnjak. Antimicrobial and Antitumor Properties of Medicinal and Spice Plants from Croatia. Biomed J Sci \& Tech Res 31(2)-2020. BJSTR. MS.ID.005068.

\section{ABSTRACT}

An overview of many years of research in the field of antimicrobial activity of medicinal plants and spices is described. The spectrum of antimicrobial activity of Croatian spices and fungicidal activity of Croatian aromatic herbs is presented. In addition, the therapeutic effect of Pelargonia radula essential oil and immunomodulatory and antitumor activity of the plant Caucalis Platycarpos $L$ is listed.

Keywords: Antimicrobial activity; Antifungal Activity; Antitumor Activity; Medicinal Plants; Spices

\section{Introduction}

Numerous scientific studies have undoubtedly proven the value of medicinal herbs that have been use in the traditional medicine for several thousand years. Many of them are still in use today, especially in the prevention and treatment of a whole range of diseases as well as prevention of numerous bacterial infections. Laboratory testing of the medicinal value of plants began as early as 1926, and today it is the main guide for the discovery of useful medicinal substances [1]. Thus, the proven chemo protective properties of aromatic herbs, their antispasmodic, antiseptic, and especially antibiotic action, opened an extremely wide area of scientific research in proving and isolating useful substances in the formulation of new medicinal products and a scientific approach in phytotherapy. In this area, there is possibility of further expansion of new medicinal products formulation, particularly antibiotics, due to global alarming inefficiency of existing and development of increasing multi-drug microbe's resistance. For the same reasons, thousands of natural and synthetic substances with antimicrobial activity have been discovered to date [2].

\section{Research Review}

Using biochemical methods (HPLC, GLC, TLC, GS-MS, etc.), numerous chemical substances and their active principles that characterize the quality and effectiveness of Croatian medicinal plants have been proven. Fungicidal activity of selected aromatic plants, which was proven by using microbiological methods is shown in Graph 1 [3] and antimicrobial activity in Table 1 [4]. Table 1 shows that many types of tested herbs, which are used as spices, have excellent antimicrobial effects and are therefore in the daily function of preserving food from deterioration, but also in preserving our health. The tested plants have a relatively wide range of microbicidal against Gram-positive and Gram-negative bacteria, as well as fungicidal against fungi of the Candida and moulds species. It is obvious that many plants contain useful biologically active substances on which past and present phytotherapy is based. It has been proven that the genetic properties of the species and the pedological microclimatic conditions of the appropriate plant 
habitat determine the amount and structure of the active substances (carbohydrates, fats, proteins, nucleic acids, enzymes and vitamins).

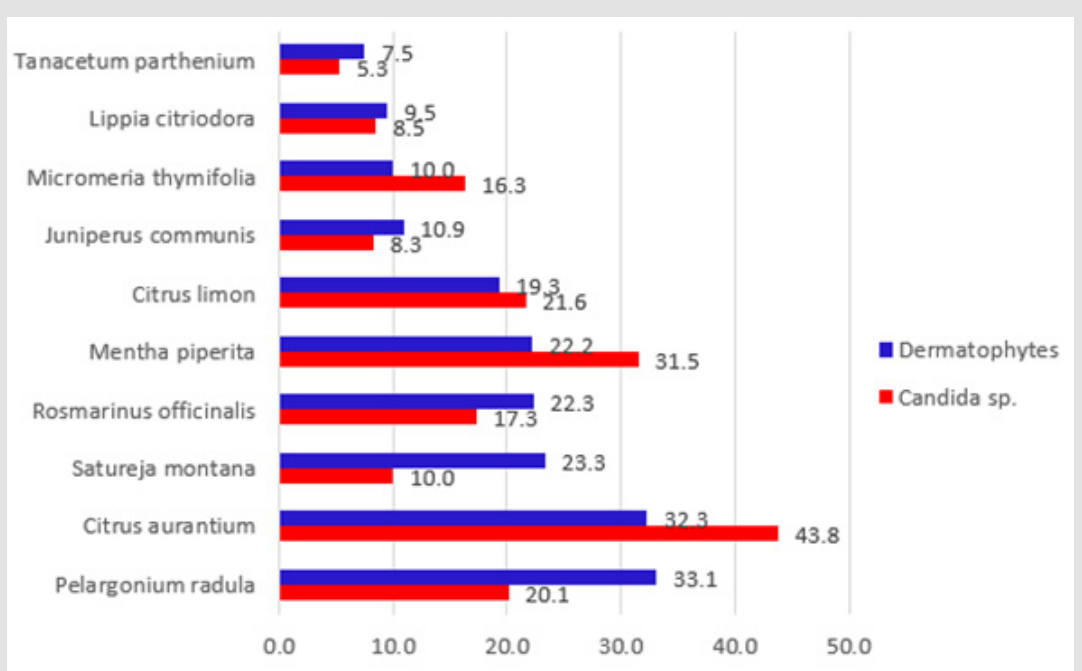

Graph 1: Comparative presentation of essential oils fungicidity of selected Croatian aromatic plants on Candidaspecies and dermatophytes (mean values of microbial growth inhibition zone in milimetars).

Table 1: Antimicrobial and antifungal effect of tested herbs essential oils (vol\%).

\begin{tabular}{|c|c|c|c|c|c|}
\hline \multirow[b]{2}{*}{ Spice } & \multirow{2}{*}{$\begin{array}{l}\text { Main compound of esssential oil } \\
\text { (vol\%) }\end{array}$} & \multicolumn{2}{|c|}{ MIC/bacteria } & \multirow[b]{2}{*}{ MIC/fungi* } & \multirow[b]{2}{*}{ MIC/moulds* } \\
\hline & & Gram-positive* & $\begin{array}{l}\text { Gram-nega- } \\
\text { tive* }\end{array}$ & & \\
\hline $\begin{array}{c}\text { Fennel } \\
\text { (Foeniculum vulgare) }\end{array}$ & $\begin{array}{l}\text { anethole } 68-95 \% \\
\text { limonene } 30-55 \%\end{array}$ & $0,25-1,0 \%$ & $0,4-2,6 \%$ & $0,025 \%$ & $0,025 \%$ \\
\hline $\begin{array}{l}\text { Laurel, Bay tree } \\
\text { (Laurus nobilis) }\end{array}$ & 1,8-cineole 30-50 \% & $0,5 \%$ & $0,5 \%$ & $0,5 \%$ & $0,5-2,2 \%$ \\
\hline $\begin{array}{c}\text { Rosemary } \\
\text { (Rosmarinus officinalis) }\end{array}$ & $\begin{array}{l}\text { cineole } 3-89 \% \\
\text { camphor } 2-14 \% \\
\text { borneol 5-20\% }\end{array}$ & $0,39-12,5 \%$ & $0,39-1,56 \%$ & $0,09-3,12 \%$ & \\
\hline $\begin{array}{c}\text { Sage } \\
\text { (Salvia officinalis) }\end{array}$ & $\begin{array}{l}\text { thujone } 40-60 \% \\
\text { cineole } 15 \% \\
\text { camphor } 10 \%\end{array}$ & $0,05-2,0 \%$ & $1,0-6,25 \%$ & $0,05-6,25 \%$ & \\
\hline Lavender (Lavandula sp.) & $\begin{array}{l}\text { linalyl acetate } 30-60 \\
\text { linalool } 25-45 \%\end{array}$ & $1,25-6,25 \%$ & $0,39-3,125 \%$ & $3,12-25 \%$ & \\
\hline $\begin{array}{l}\text { Mellisa, Lemon balm (Melis- } \\
\text { sa officinalis) }\end{array}$ & $\begin{array}{l}\text { citral } 30 \% \\
\text { citronellal } 40 \%\end{array}$ & $1,56 \%$ & $3,125 \%$ & $0,19-2 \%$ & \\
\hline Basil (Ocimum basilicum L.) & $\begin{array}{c}\text { linalool 40-50\% } \\
\text { eugenol 1-19\% } \\
\text { methyl chavicol 3-31\% }\end{array}$ & & & & $0,35-33 \%$ \\
\hline $\begin{array}{c}\text { Chilli peppers (Capsicum } \\
\text { annuum) }\end{array}$ & capsaicin 80-90 \% & $0,00006-0,0005 \%$ & $\begin{array}{l}0,00025- \\
0,0005 \%\end{array}$ & & \\
\hline $\begin{array}{c}\text { Cinnamon tree } \\
\text { (Cinnamomum ceylonicum, } \\
\text { Cinnamomum cassia) } \\
\text { (referent spice) }\end{array}$ & $\begin{array}{l}\text { cinnamaldehyde 65-75 \% } \\
\text { trans-cinnamic acid 5-10 \% }\end{array}$ & $0,02 \%$ & $0,02 \%$ & $0,16 \%$ & $0,06-15 \%$ \\
\hline
\end{tabular}


Numerous studies have shown that the basic of the healing properties of a plant, in general, and in particular their antimicrobial efficacy, is determined by the chemical structure of glycosides, flavonoids, saponins, tannins and essential oils, including many of their components (terpenes, geraniol, terpenoids, thymol, carvacrol, Phenolpropanes, eugenol, cinnamaldehyde, vanillin, ketones, allicin, isothiocyanates and others). The antifungal activity of the Pelargonia radula essential oil was investigeted in vitro, and then the therapeutic effect was confirmed in vivo in cats. The outcome of trichophytosis (Trichophyton Mentagrophytes, Mycrosporum Gypseum) therapy in cats is shown in Figures 1\&2 [5]. Based on notes on Croatian traditional medicine and experiments on animal models (rats and mice), the antitumor effect of the water extract from the plant Caucalis platycarpos $L$. have been proven. The results suggest that the antitumor effect is probably due to stimulation of the immune system of the tumour host [6].



Figure 1: Before treatment of trichophytosis.

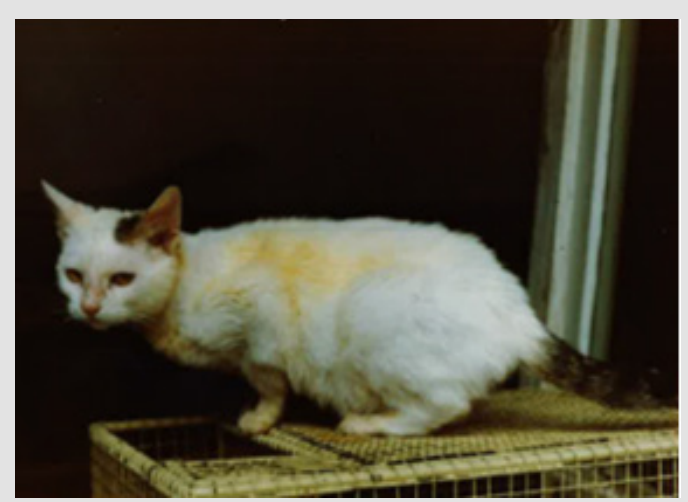

Figure 2: After 30 days of therapy with 5\% lotion with Pelargonia radula essential oil.

\section{Conclusion}

Our presented studies shows that many aromatic and spicy plants in Croatia contain substances with a wide range of antimicrobial activity. Essential oil of Pelargonia Radula have good antifungal properties and shows successful treatment of trichophytosis in cats. Water extracts of Caucalis Platycarpos L. have significant immunomodulatory and antitumor properties.

\section{References}

1. Lai PK, Rov J (2004) Antimicrobial and chemopreventive properties of herbs and spices. Curr Med Chem. 11(11): 1451-1460.

2. Pepeljnjak S, Kozaric Z (2019) Začini, mikrobi, antimikrobna svojstva i primjena. Medicinska naklada Zagreb, Akademija medicinskih znanosti Hrvatske, Kolegij farmaceutskih znanosti. Zagreb pp. 334.

3. Pepeljnjak S (2019) Pregled antifungalnog djelovanja eteričnih ulja bilja Hrvatske. Zbornik radova, Znanstveni skup Zdravlje, kultura, priroda. Akademija medicinskih znanosti Hrvatske pp. 34-39.

4. Pepeljnjak S (2016) Antimikrobno djelovanje začinskog bilja. Zbornik radova, Zdravlje: rezultat ravnoteže prirode i znanosti. Hrvatski liječnički zbor i Udruga za promicanje zdravlja Korak po korak do zdravlja. Klanjec pp. 16-25.

5. Pepeljnjak S, Kosalec I, Kalođera Z, Kuštrak D (2003) Natural antimycotics from Croatia plants. Plant-derived antimycotics, current trends and future prospects. In Mahendra Rai, Donatella Mares(Eds.), The Haworth Press Inc, Oxford, New York, London pp. 49-79.

6. Fatović Ferenčić S, Kujundžić N, Pećina M (2017) From the Traditional Recipe to the Modern Remedy: The Antitumoural activity of the small burr parsley (Caucalis platycarpos). Exploring Traditional Medicine. In PF McGrath (Eds.), P Tout, IAP for Health. Section 41(18): 174-183. 
ISSN: 2574-1241

DOI: 10.26717/BJSTR.2020.31.005068

S Pepeljnjak. Biomed J Sci \& Tech Res

(c) (P) This work is licensed under Creative BY Commons Attribution 4.0 License

Submission Link: https://biomedres.us/submit-manuscript.php

$\begin{array}{ll}\text { BIOMEDICAL } & \text { Assets of Publishing with us } \\ \text { RESEARCHES } & \text { - Global archiving of articles } \\ \text { - Immediate, unrestricted online access }\end{array}$

